\title{
HRG wt Allele
}

National Cancer Institute

\section{Source}

National Cancer Institute. HRG wt Allele. NCI Thesaurus. Code C88168.

Human HRG wild-type allele is located in the vicinity of $3 q 27$ and is approximately $12 \mathrm{~kb}$ in length. This allele, which encodes histidine-rich glycoprotein, may play a role in both extracellular ion sequestration and coagulation. Mutation of the gene is associated with thrombophilia. 